\title{
Marco Antonio Coronel Ramos, La filología humanística y los textos sagrados: La Epístola a los Romanos en versión de Sebastián Castellio, Valencia, Institució Alfons el Magnanim, 2010, 424 pp.
}

La cuestión bíblica y en particular la traducción de la Biblia en los siglos XV y XVI tuvo particular relevancia. El autor ha dedicado una extensa revisión de las condiciones en que se produjo el desarrollo de los estudios bíblicos para acercar al lector al ambiente en que Castellio realizó su versión. Se trata de uno de los textos más leídos e interpretados de esta época de búsqueda y controversia. M. A. Coronel ha contextualizado la versión de Castellio en la primera parte de la obra, partiendo de un cúmulo de circunstancias que determinan un renovado interés por los textos.

Comienza por recordar la función de la exégesis en el desarrollo de la disputa tardo medieval sobre la autoridad del papado en el gobierno temporal y el derecho de propiedad sobre sus bienes. Mientras que el estudio y comentario de la Biblia había sido una de las tareas intelectuales más características de la alta Edad Media, después de superado el año mil, se orientaba sobre todo a ilustrar una incipiente doctrina teológica. En cambio, la autoridad temporal había sido discutida en la lucha de las investiduras y particularmente en las islas Británicas. Partiendo de estos problemas políticos, y de la disidencia religiosa de pequeñas comunidades, se arroja luz sobre la trascendencia de la traducción de los textos sagrados a las lenguas vernáculas. Este resumen de la historia pretende integrar multitud de contribuciones particulares de distintos estudiosos que se interesaron por comprender y difundir la Biblia.

De ahí se despliega la diversidad de facetas que presenta en el Humanismo: la Biblia como documento histórico, la filología bíblica animada por los avances en la filología clásica, la traducción de la Biblia con el estudio de las versiones en las lenguas antiguas (griego, hebreo y siriaco en relación con la Vulgata) y traducciones vernáculas. Se hace memoria de la actividad de los humanistas europeos que trasladan el método de depuración de los textos clásicos a la filología bíblica. La revisión de esta historia de los estudios hasta Castellio no pretende ser estrictamente cronológica, sino representar esta diversidad de los estudios humanísticos. El autor enlaza temas y factores culturales no solamente de los antecedentes, sino de la cultura bíblica posterior a la fase intensa de la Reforma. Ofrece motivos para entender desde dentro la razón de determinados intereses, de algunas actitudes hacia la traducción de los textos que se acentúan a través del tiempo.

Pero en esta primera parte no se introduce la figura de Castellio, que ocupa la segunda. La técnica de traducción y la polémica sobre las traducciones vernáculas ocupa un lugar central, que anticipa el acceso a Castellio. Se nos presenta el traductor, recordado entre aquellos que defendieron la tolerancia religiosa e ideológica consecuente con su formación clásica humanística. El ambiente de las imprentas en Basilea facilitaba la renovación de los métodos de edición de los clásicos. La sensibilidad hacia el problema de la tolerancia es evidente ya en su primera juventud, cuando conoció a Calvino. Pero además se compromete con una enérgica protesta contra la violencia de la ejecución de Servet. En su faceta de estudioso de los textos procuraba que "la altura retórica de la lengua bíblica", se reflejara en la lengua de destino. Castellio combina esa actividad filológica de estudio y revisión, además de la interpretación de los textos. Por eso, hay una sección dedicada a las traducciones bíblicas de este antiguo estudiante de Lyon, que editaría su Biblia latina en 1551. En la segunda edición le añadió la Historia judaica de Flavio Josefo. Editó primero una traducción del Pentateuco que tituló Moses Latinus y una del Salterio; después realizó varias ediciones del Nuevo Testamento en latín, una de ellas, la de 1572, con traducción francesa, aprovechando su traducción francesa de la Biblia de 1555.

Una vez analizada la metodología del humanista, se consagra un capítulo a la literalidad de la traducción de la Epístola a los Romanos. Esta es la parte (pp. 183- 386) que recoge 
la comparación minuciosa de las distintas versiones humanistas con el texto griego y la Vulgata, con las variantes concretas. Se comenta el vocabulario elegido para cada una y el orden de palabras. M. A. Coronel confronta las variantes y los pasajes donde Castellio presenta un criterio audaz respecto de la tradición. Así decidía seguir el ordo rectus latino clásico frente a la Vulgata que mantenía el orden del original griego. La influencia de la filología bíblica de Erasmo queda en todo caso patente. Pero también compara el criterio de Castellio con el de Benito Arias Montano y con el seguido por Lutero y Casiodoro de Reina. En el apartado titulado "Traducción y doctrina" contrapone las actitudes y resultados de Erasmo y Castellio: "Erasmo es un filólogo que se reviste de escriturista (...) Castellio es un biblista que se mete a filólogo" (p. 292). Este aserto, tal vez algo atrevido, se justifica en su contexto con los datos que desvelan el criterio con que cada uno corrige o respeta el texto tradicional. Y en ese afán, Castellio se atreve a volver a traducir lo que consideraba errores de la Vulgata, una tendencia que se señala como característica general de las traducciones vernáculas de Lutero, Zwingli, Bèze, la encargada por el rey Jorge, la inglesa de Ginebra, las de Pineda, Enzinas y Reina. Después se relaciona esta variedad con la doctrina que defendían por medio de tales traducciones comparando pasajes concretos. Para la interpretación de algunas palabras y giros traducidos recurre a anotaciones de Juan Luis Vives y de Lorenzo Valla.

Téngase en cuenta que la orientación del análisis que realiza M. A. Coronel está abierta a ese horizonte de la traducción europea y no al panorama de las versiones vernáculas en España, que por sí es un tema complicado desde cualquier punto de vista, como demuestran los estudios de los últimos diez años.

Por fin, en el epílogo, se analiza la interpretación de Castellio, y el compromiso con los resultados de una reflexión audaz sobre la tradición. La figura de Castellio queda perfilada en su apuesta por dignificar al hombre.

María Asunción Sánchez Manzano

Universidad de León 